\title{
Body in fashion films: The new net-aesthetic era
}

\author{
Simonetta Buffo, Università Cattolica del Sacro Cuore Milano, Istituto Marangoni Milano \\ simonetta.buffo@unicatt.it
}

\begin{abstract}
With "fashion film" we mean those online videos that are peculiar to fashion industry and are developing their own language and new types of brand narration. The field of study presented here to is related to language. The objective is indeed to better understand how this new communication tool has influenced the conventional language of fashion images through the development of new codes or a transformation of the existing ones. The object under examination is, in particular, the body as a preferred communication code within this industry. This body is not viewed by fashion as a simple object to dress, but rather as a mediating channel between the individual's individuality and their need for communication, or better to say, their need to establish a relationship within its context. To do so, it seemed appropriate to start with the examination of the history of fashion images by concisely analysing how the body has changed its communicative role over the decades. Further analysis was then conducted in order to focus on the new meaning undertaken by the body in fashion films. As a consequence, the result is a complex and extremely rich picture.
\end{abstract}

\section{Keywords}

fashion film, fashion language, codes, fashion photography, fashion images

\section{Body in fashion: codes and languages}

Body as social product (Bourdieu, 1987) is an important communication tool that builds and conveys its own identity: the body mediates every relationship between the individual and the social context he belongs to, as well as it primarily establishes a self-relationship to gain identity.

In a semiotic perspective, the body reveals the form of the individual-signifier also through garments, which then translate the individual-signified's being and essence, that is his values.

In his book The Fashion System, Barthes (1967) starts from the question: "... but which body is the Fashion garment to signify?" (p. 269).

Body and garment mutually generate meaning: body and fashion attract and repel each other, in a constant game of new significations for new significances.

French semiologist Greimas (1983) states that body is the place where we find values, which moderate the relationship between subject and him/herself. This relationship results from a process, which therefore leads the individual to live his own body with awareness and self-determination, even more in modern times the individual is inspired by patterns coming often from images of the various media he is subjected to, so as to feel comfortable in his own social relationships.

In particular, fashion images have interpreted the woman and her body over the years - through these images one can understand how women have been conceived, what has been and is still transgressive and what are the stereotypes related to body.

Garments represent the language the body adopts to communicate itself: garments redefine and narrativize the body by contextualizing it. Besides the fashion of garments, there is therefore the fashion of the body, which is continuously re-semanticized as a bearer of quintessential values in different historical, social and costume periods. Indeed, fashion images are not about general but alive clothes body's aim is moulding and giving fashion world a soul. More specifically, we could say that body in fashion becomes a narrator through the use of images - we can in 
fact experience a dream when looking at those women shown in the pictures from the early $20^{\text {th }}$ century to the present day. Fashion images' primary purpose was to translate the idea of beauty by showing a perfect beauty of a perfect woman for a perfect dress. That body was consequently perfect.

By retracing the history of fashion images, we see how the body interprets this abstract model of perfection over the years and, especially, how these images have always made a dream of perfection come true by codifying the idea of beauty into ever-changing languages. Body is the place of life, experiences, feelings; it is also the object and instrument used to communicate and seduce the others, and it is forced to adapt, at least partially, to a changing gaze.

\section{Fashion body through the time: a short history}

Albert Liberman, Vogue's artistic and editorial director from 1941 to 1994, stated that fashion photography is not a photo about clothes, but rather a photo about a woman (Angeletti, Oliva, 2012).

Starting off with this suggestion and adopting a semiotic approach, our attempt is to interpret the body, which is narrated by fashion photography as shape of a (fashion) content, both content and shape being seen over the time.

For this reason, we have seen the body as code, which communicates the classic fashion luxury exclusivity and distinctiveness.

It is certainly true that photography is often outlined in semiotics as indexical sign, or just index, due to the so-called physical continuity between sign and object

(...) The current presence of photography informs us that, in a certain moment, the photographed object was in front of the camera lens. (Volli, 2003, p. 28; translated by author)

In my previous study (Buffo, 2012), I have however shown how fashion images have been able to structure an authentic language over time, which is as highly recognizable and clearly characterized by rules, symbols and intrinsic codes as any other kind of language.

In the introduction to this book, we read:

In order to formulate this opinion, I have spent many days browsing through the pages from the old editions of the premier fashion magazine Vogue Italia, and collecting the yesterday's and today's ad campaigns. Likewise, I have watched the online short movies of the leading brands. This was the beginning of an extremely fascinating and interesting experience which allowed me to outline the journey made by fashion, even if it was not always a conscious path yet clear anyway. (p. 9) (translated by author)

We are considering only one code of this language, because it is probably the most crucial in building fashion brand imageries: the body code and its evolution over time.

Our findings lead us to identify four different ways of living and interpreting the body in the last millennium
a Art Body
b Narrating Body
c Free Body
d Desire Body.

Each of these bodies had its own expressive peak in a given historical, socio-cultural and even artistic context. This is the reason why each body characterizes and is characterized by its period of origin and development. All these categories are however not limited to their development period, but rather they are still enriching the fashion language over the decades, as it is evident by looking at the contemporary photographers. In order to provide a better insight into each category, we will therefore take several contemporary fashion photographers as an example, whose style recalls one of these four interpretations of the body code, and without forgetting that fashion language is so rich and unique thanks to the contamination 
and combination of these great masters of photography through the times.

Let's see them one by one.

The first is Body as Art, which first appeared in the U.S. on the pages of the recently born Vogue magazine.

Indeed, Vogue meant to be the first fashion magazine to serve as trends lover and promoter through fashion images, and it started as a magazine addressed to a special, feminine, elitist, cultured and highbrow audience.

In 1913, Mr. Condé Nast (just a few years after the purchasing of that small magazine, i.e. Vogue), decided to confide in a photographer so as not to simply show garments but rather create trendsetting images in terms of taste, clothing and any other topic to arouse interest in this narrow, selected and exclusive female audience belonging to the American high society. The photographer's name was Adolf de Meyer, the first to establish a close relationship between art and fashion, between pure research and what will be later called cultural industry. He infused not only his photographic skills in fashion images but primarily his sophisticated style, which became firmly popular during those years. Thanks to him, an aesthetic taste took on a broader meaning for the first time, thus allowing us to talk about aesthetic massification.

His images depicted imageries where the dream was directly exhibited and women looked ethereal and unreal, unconscious models of the new fashion world. Neither their body nor their garments were the protagonists, but it was rather the dreamlike atmosphere able to turn every woman into a model to create that desire always needed by fashion.

As mentioned before, this photographic signature didn't fade out completely, as we still find the same dreamy environment in some important contemporary fashion photographers: one of them being of course Paolo Roversi (1947). His style is also blurred and surreal and decisively pictorial, where bodies seem celestial and impalpable creatures, noblewomen of past eras deprived of their phys- icality in favour of a polite and timeless femininity.

Just a few years after De Meyer, Horst P. Horst (1906-1999) will be however the first fashion photographer to celebrate the body by recovering its true authenticity model of the other great photographer G. Hoyningen-Huene (1900-1968), at the beginning it was only as photographer that Horst turned De Meyer's sculptural body into pure sensuality, a body in constant balance between image and imagery. One of his most famous images portrays a woman on her back, wearing a corset drawn by Mainbocher. This image, structured as a trompe l'oeil, shows only the back chest of the girl, without legs, as if she were leaning against a shelf. The light effects and the malicious slip-on corset, with its ribbons lasciviously falling on the shelf, are in harmony with this perfect and tonic (though not too muscular) model's body, thus creating a soft aura of fascination. This is one of the first images to celebrate the body and an idea of beauty as a harmonious balance of shapes.

Begun by Horst, this trend then took on different but always consistent elements through other great fashion photographers' lenses, such as Irving Penn (1917-2009) in the Fifties and Sixties, who completely sacrificed the model's identity and personality in his quest for contemplation and aesthetic gratification - the bodies he chose are therefore the result of an exquisite and formal exercise made up of lines, volumes, silhouettes and chromatic values.

The same pleasure in the body's aesthetic contemplation, still in perfect balance between image and imagery, can be found today in the Peruvian artist Mario Testino, born in Lima in 1954. He was indeed absolutely able to portray celebrities with magistral skills, thus restoring their most authentic identity: his famous exhibition showing the pictures of Princess Diana is an evident example, but we also have to mention his fashion shots where the body shapes (and garments) are celebrated in their harmonious naturalness, which is sensually provocative yet never vulgar. 
Continuing our historical journey, we find a new type of body code that was first interpreted by Richard Avedon (19232004), who was the fashion photographer that turned models into actresses.

The situations represented by Avedon during the first phase of his career, which we could consider as the most narrative phase, nourished mythological imageries where reality and dream coexisted together and complemented each other, whereas the heroines populating these legendary stories looked like celestial women of a near but distant world at the same time. The goal of his images was

that of being not so much a picture of a well-dressed beautiful woman as a revelatory glimpse of a feminine psyche confronted with a situation involving action or passion. (Sargeant, November 8, 1958)

His storytelling ability was combined with a style compliant with the ongoing trends of fashion images of the second half of the Twentieth century, which aimed at setting a global style and life attitude rather than showing a simple parade of garments. Thanks to Avedon, the Body becomes in fact a Narrating Body: his images displays ever-young bodies with perfect shapes and movements. The body started to develop its own language, fully based on elegance and refinement, exclusivity and luxury. An example is the famous image for Dior (1955), where the model Dovima (acronym of Dorothy Virginia Margaret Juba, 1927-1990) stands between two huge elephants and spreads her arms upward in an extremely elegant gesture. The winding body of the model and her refined composure communicate an authentic sensuality in a surreal context.

Throughout the years, the body exacerbates even more its storytelling aptitude in photography, as it is evident today in photographers who show different styles and photographic personalities, such as David LaChapelle, Peter Lindbergh, Steven Meisel and Annie Leibovitz just to name a few.

It's worth mentioning the American photographer Steven Meisel (1954), and the cover pages he published on Vogue Italia during his 20-years collaboration with the magazine. Through his shots, he narrated many different stories (some related to ethical issues) by showing frames of imaginary and hypothetical movies, such as in "Cinematic" which is focused on the violence against women (Vogue Italia, 2014) or in "State of emergency," focused on the terrorism (Vogue Italia, 2016).

Coming back to the Sixties, we now find a body that changes its social role. In fact, the youth movements, above all, proposed a new role for the body that became subject of several battles for social and sexual emancipation - the body is exhibited and sometimes paraded. One of the greatest interpreters of fashion images was the revolutionary David Baily, who is portrayed in the movie Blow Up by Michelangelo Antonioni (1966), a personal friend of Mary Quant (the terrible girl who invented the miniskirt) and Mick Jagger, voice of the Rolling Stones. He was the photographer who best interpreted this breathe of fresh air that London was able to express during those years. In his pictures, uninhibited bodies are charged with new expressions and contents, thus resulting strongly erotic and decisively provocative. The body becomes Free Body, free to show up, express itself and create a new language while the model shows herself uninhibited under the lens of his camera (Lehndorff Trulzsch, 1986).

The landmark is therefore the displacement from a dressed body to a materialized body. Fashion begins to enrich the body with more physical vibrancy and sexual connotation so as to acquire more visibility and a completely different social dignity from the past. Fashion photography tends to develop an imagery oriented towards the transgression of sexual behaviours while body becomes object and subject of the Desire Body.

Another fashion photographer immediately after the '70s, and very well-known for his strongly erotic images, was the Parisian Guy Bourdin. In his photographs the product is independent - what matters is provoking through sexual allusions mixed with violence and blood doses. His bod- 
ies are conscious bodies involved in the scenic fiction that aims at nurturing the desire. A few years later, Helmut Newton made the woman's body a conscious object of voyeurism, a carnal body proud of showing off its materiality. It's worth mentioning a new and forerunner aspect of recent trends, that is the body artificiality: the paraded body is evidently moulded by sophisticated beauty treatments and lined up with the artificiality frontier. A so cold perfection that bodies seem to be almost bionic. He said:

"In my work we operate a distinction between models and real people. We never consider models equal to real people" (Newton, 1984, p. 13) $\left({ }^{*} \mathrm{TN}\right)$. And he also added: "The fashionable woman is this: an infinite amount of gears." (Newton, 1984, p. 10) $(* \mathrm{TN})$

This strong physicality of bodies visible in fashion images remains also in the Eighties and increasingly extends to male bodies, which become at the same time object and subject of desire - muscle-bound, gym built, perfect bodies.

Herb Ritts (1952-2002) was one of the most iconic fashion photographers of the Eighties and Nineties - aloof from garments and completely focused on both male and female bodies, Ritts shows nurtured and clean-cut bodies with massive workout and expensive beauty treatments. The artificial seems to clash with the natural body look to then perfectly blend together. The 1999 Pirelli calendar is a clear statement of Ritt's approach - the American athlete Alek Wek is covered with a shiny paint overlapping his body which enhances even more its perfection. The body becomes a dress.

If we consider the contemporary photographers, it's absolutely worth mentioning the German photographer Ellen von Unwerth (1954): the most authentic Newton's heir, given her voyeuristic style and the way she treats the female body. Differently from Newton, the location of her pictures plays a greater role and the scene theatricalization becomes much more filmic, but the body is a conscious protagonist pleased with the desire.
During the Twentieth century, for example, woman's clothing has become more and more reduced and simplified, more dynamic and ascending upwards. If in the early years of the century the female body representations were made up of corpulent silhouettes, which tended to recall the heaviness of the earthly wealth, in the following decades the body has become decisively thinner and lighter. And slimming remedies and diets have progressively become the standard for both genders ... (Codeluppi, 2012, p. 7) $\left({ }^{*} \mathrm{TN}\right)$

In this social process, technology plays an important role, also because images show an artificial body that can crumble and then put back together itself.

In the 1999 the movie "Matrix" contributed to imagine a pixeled body, in a world where technology is the real protagonist of an unreal life.

\section{New millennium: between hyper-bodies and pixeled bodies}

In his volume The Matrix (2010), the philosopher and sociologist Žižek observes that the innovation of this movie is not witnessing the fortunes of a hero who acts in an artificial, manipulated and controlled universe, but rather that this universe becomes a virtual reality, thus marking a radical reduction of our sensorial experiences and acknowledging the images a huge seductive power.

Images do not simulate reality, but rather hide its incompleteness and inconsistency:

The film is not wrong when highlighting the EXISTENCE of the Real beyond the simulation of the virtual reality - as Morpheus says to Neo when showing him the ruined landscape of Chicago: "Welcome to the desert of the Real" (...) the function of every single Matrix is to conceal this inconsistency... (Žižek, 2010, p. 16)

The film Matrix was able to foresee the current, real trend of 2018 - the dichotomy between real reality and virtual reality. Images mediate between these two univers- 
es and serve as bearers of new stories and generators of new suggestions.

The individual completes the search for an abstract aesthetic perfection to become a body-image, an envelope that makes use of the aesthetic surgery to achieve its own goal and become a body to be displayed on a shop window, precisely a "shop-windowed body" (Codeluppi, 2007).

Today's individual only wants to like himself even more than being liked by others. This absolutely matches with the current post-modern or hyper-modern society, where the individualism trend is fully underway and every choice made by the individual privileges the self to the detriment of the surrounding. Today we seek refuge in ourselves to satisfy personal and immediate pleasures, in a mood of common mistrust in the social fabric and future. Selfies are the apologia of this trend.

Codeluppi also says about the body:

It is therefore inevitable that individuals feel able to freely manipulate their body to achieve those communication goals they set for themselves. This gives life to the "flow body", namely a body in a state of permanent change, having no fixed boundaries nor identities and attempting at not having to depend on the laws of biology. (Codeluppi, 2012, p. 114, translated by author)

The artificial invades the natural, the body often becomes a hyper-body. Since the beginning of the new Millennium, body has become a flow-body: nothing is fixed and body looks like a packaging that can be transformed and manipulated. The body becomes a malleable surface on which to draw its identity. Artificial invades the natural, and the body becomes a hyper-body.

This hyper-body often becomes the protagonist of fashion images - motionless bodies featuring unnatural poses, inexpressive eyes, masks deleting the faces or even covered and hidden faces to cancel their identity.

Slender, hybrid bodies between mannequins and dolls or even puppets that only live virtually weightless, transsexual, feeble creatures. Craig McDean, Tim Walker, Miles Aldridge, Steven Klein are just few of the photographers who mainly contributed to narrate artificial, manipulated, abstract bodies.

These body images animate and motivate the consumption experience by nurturing fictional imageries that escape the uncertainty of what is real, thus translating the individual's fulfilment into the certainty given by the purchased objects. Therefore, the body dissolves into image, in the enchantment of the mise-en-scène.

The idea of Beauty has evidently changed and fashion market is exploring new frontiers: five years ago, Miuccia Prada said:

\footnotetext{
"Ugly is attractive, ugly is exciting. Maybe because it is newer," she said. "The investigation of ugliness is, to me, more interesting than the bourgeois idea of beauty. And why? Because ugly is human. It touches the bad and the dirty side of people. You know, this might have been a scandal in fashion but in other fields of art it is common: in painting and in movies it was so common to see ugliness." (Duffin, 2013)
}

In reaction to the New Millennium consumption models and this hyper-modern (or post-modern) individualist individual, fashion suggests an anti-model: fashion does not seek the Beauty anymore, but rather different ideas of beauty (even achieving the ugliness sometimes), because there is not only one Beauty to be inspired by but everyone is free to interpret, mould and express his/her own beauty.

Fashion films play a crucial role in this body evolution, especially because they were born for the web. Moreover, new technologies are so much influencing the body perception and representation that we can easily state fashion films are developing a new net-aesthetics by using new codes and creating new kinds of language.

Indeed, bodies in fashion films do not appear as a model to strive for, that is the idea of a contemplated beauty. Fashion films rather show Post-Modern or HyperModern bodies: they reflect those individuals who are focused on themselves, determined to state their individuality and uniqueness, confident of being able 
to be true to themselves without compromises, living for emotions. Therefore, in the fashion film's dreamy world there are no right nor wrong models: what emerges is the possibility to always be authentic thanks to fashion and regardless of age, sex, gender and species. There is no "right beauty" in the represented body as this is a body that is not apparently interested in its physicality.

Showstudio.com, an interactive fashion platform, nowadays famous as House of Fashion Film, also investigated the idea of the Ugly in a fashion film. The fashion film title is "Beyond the glass" by Ruth Hogben. In this short-movie, woman's body does not appear in its physicality but is rather the simulacrum of itself, continuously committed in a chameleonic metamorphosis - a body that continuously moves, escapes and chases, that is frightened and frightful (bearing in mind numerous Hitchcockian quotations). This body is unreal and pixeled, which leads us into the Other cyberspace world ruled by some Matrix.

It is precisely from the fashion films that new images showing moving bodies emerge as interpreters of new fashion tales.

Over the last decade, fashion films have indeed become a strongly relevant phenomenon for fashion industry: we find those made by brands to show their collections, as well as fashion films dedicated to create new brand narration forms (such as the Miu Miu's with the "Women's Tales" saga). Likewise, we also find fashion films made by some fashion e-magazines like Nowness, or fashion e-commerce like Mytheresa.com in collaboration with several fashion brands. Moreover, there are some online created by some novice filmmakers and presented at the worldwide fashion film festivals or simply uploaded on some target websites, such as a Vimeo channel, that is fully independent and dedicated to fashion films.

As Uhlirova (2013) writes,

Fashion film's recent proliferation on the Internet and beyond has demanded that we seriously rethink what role the moving image can play within fashion (...). (p. 118)

The clear trend (or the need) of fashion communication is therefore to develop a new language for those moving images where the body code is acknowledged a key aesthetic and narrative role.

We therefore try to understand if there are some recurring types of body in these fashion films that affect the world of the fashion images in general, to then re-think at the language of the images in the New Millennium, which can be above all identified as fashion images, whether static or moving.

\section{Body in fashion film: the new net-aesthetic era}

(...) fashion media partecipate in the normalization and codification of the body. (Shinkle, 2013, p. 176)

Fashion films are a particular category of online videos, whose origin is really uncertain. "100 years offashion film: frameworks and histories" is one of the Uhlirova's articles (2013), whose name is given to the fact that:

The article carefully negotiates the fashion film as a form that must be considered within multiple frameworks, namely cinema and the new media, fashion industry, entertainment, and art practice. (p. 237)

However, we will not hereunder consider the fashion industry videos as something outside the web.

In fact, several communicative models (i.e. the Jakobson's in 1963) state that regardless of the communicative flow, the channel influences the message production both in the contents and form selection, thus adapting codes and rules to the new context in which the message acts.

We will therefore consider only the online fashion videos in order to understand their features and influences that may directly come from the virtual world of the web. 
Based on our previous studies, it also results that fashion films are a separate category of online branded videos, and not only because they have a distinctive name which makes them different from the others but rather because we think (and will try to prove) they were able to develop their own communicative identity to then become a communication tool used also in other industries. It might be worth considering that in 2014 the BMW car manufacturer released the online video starred by Tilda Swinton and named the movie just as fashion film.

On the matter Uhlirova stated (2013) “

As a heterogeneous cultural form with no clearly predefined stylistic criteria or conventions, the fashion film eludes any attempt at a neat classification as genre. (p. 120)

In our opinion, many signals lead us today to consider that fashion films are a full communication gender.

As we already mentioned one year ago (2017),

Since the beginning of the new Millennium, fashion has developed new types of messages concerning the contents, producing new techniques and showing its ability to use new technologies with a greater eagerness and strength than other markets. (...)

Additionally, in all the main fashion cities in the world we find Fashion Film Festivals. There are at least 4 today considering only London, of which the first in absolute was organized by Central Saint Martins in 2006, Fashion in Film; the second city that hosted this event was Paris, with ASVOFF, organized by the fashion designer and blogger Diane Pernet, and a festival that has today achieved its ninth edition. (Buffo, 2017, pp. 295-296)

Today there is even a fully independent Vimeo channel whose name is, indeed, $A$ Fashion Film Channel.

It's however hard to determine exactly the time when the first fashion film was put online. We therefore prefer to consider a timeframe when everything started to take shape, that is the beginning of the
New Millennium when the web underwent a considerable development that is still ongoing.

This abovementioned new communicative identity works on two aspects - the first is the new brand narrations, regardless of whether the video develops or not a narrative plot; the second is represented by a new language made up of new codes.

Indeed, fashion films are the natural evolution of the languishing fashion images but, at the same time, they are their revolution. Fashion films have managed to turn the traditional brand communication into bodies' movements, which are often exciting and suggestive and sometimes purely aesthetical.

\footnotetext{
The fashion image has been historically seen as static, but digital media offer a departure from the past by introducing a constant flow of moving images and active spectatorship. The idea of "permanent presence" suggests fashion is constantly renewed and at the same time caught in the here and now. (Khan, 2012, p. 248)
}

What we are about to analyse is how the body is narrativized in these fashion films (whether narrative or not), as the body is often their lynchpin.

\begin{abstract}
Several fashion films, which belongs to "The Fashion Body", make this connection between photography and history of the moving image through a renewed focus on the body. (...) The cinematic film creates a sense of linear time. The photograph is forever locked in the past and the digital image offers a permanent presence. Fashion is caught in its own reflection locked in the past, it has begun to move and is part of a new and permanent presence. When we watch the body films inside the frames of "The Fashion Body," we remember that a symbolic notion is created through movement - today fashion is no longer still. (Khan, 2012, p. 249)
\end{abstract}

For about 9 years (since we started to deal with fashion communication), we have been carefully observing this new communication object: we have looked at the fashion films made by the most important 
fashion brands, as well as the online fashion films of Nowness or ASVOFF, the Vimeo section fully dedicated to fashion films, and even the online fashion-mags that often offer their own production, without mentioning all the rest offered by the net. One of the most stimulating aspects for our curiosity is related to how the body is treated and become a fundamental code to produce fashion tales. We are also aware that our observation and categorization cannot fully complete the fashion films supply on the web and, in fact, this is not our aim as we recognize the impossibility of such pretension. The online language in general, and the fashion films language in particular, is living a continuous experimentation and transformation.

As Uhlirova said (2013):

If we accept fashion film as a genre, we have to accept a notion of a genre not as a static set of stylistic or material commonalities but as an ever-evolving historically bound category which is fluid and at time even self-contradictory. (p. 122)

The result of our observation is however that these types of "bodies" represent the main current fashion trends, as they are mostly recurring and often mark an important change compared to the iconographic tradition of fashion.

We think that this type of interpretation is useful to grasp and handle the fashion communication of the New Millennium. Even less than fashion photos, fashion films do not reproduce clothes but rather offer ways of interpreting the contemporary women and men, thus showing their contradictions and complexities and telling the ways through which the individuals perceive themselves and the surroundings with their body.

Analysing these videos will be also interesting to retrace the important history of the fashion images.

What immediately surprises is that body in fashion films is declined in different and multiple kind of stories. Fashion films have furtherly enriched the value and semantic content of the "body" sign, thus celebrating its communicative poten- tial in a market that more than any other needs to create always new imageries.

The analysis leads us to detect two apparently opposite macro-categories:

\section{A. Concrete Body}

B. Abstract Body

As the code can influence a language, so each of the aforementioned codes mostly belongs to and characterises respective and different categories of fashion films.

A. The first is the Concrete Body: we are talking about a real body as it appears in its everyday life, where its individuality - and not its appearance or shape - is shown. These characters do not show always perfect bodies, even though they are models, because their personality is the real protagonist.

This interpretation of body is the equivalent in the filmic language of the previously mentioned narrating body of fashion photography. It's a body that narrates and talks about itself, reveals and shows itself.

Within this category, a further distinction is possible between narrative body and hyper-realistic body.

A.1. A narrative body is typically cinematic: it is a body that walks along the fashion film development, makes the sequence of events possible, sometimes shows its evolution, where the emotions of the character evolve as well. This body is characterised by its actions and the choices that the character makes.

Within this category, body carries out a storytelling project, with or without a narrative plot. First of all, a narrating body shows us an individual's story, be this a woman or man, a personal story with the individual's feelings and interactions with the context, as well as her/his interactions with the others. This individual is sometimes shown while he is living an internal or external conflict, but his moment of redemption is rarely displayed. This body often struggles and fights or simply shows the signs of its weariness, its face does not smile, rather the emerging feeling is that of individuals who are tireless fighters. An example could be the fashion film by Peter 
Lindbergh for Vogue, released at the end of 2016. We are talking about Walking, the Peter Lindbergh's tribute to the late Editorin-Chief of Vogue Italia, Franca Sozzani.

Its images show some of the most popular models, who are more or less young, such as Mila Jovovich, Carolyn Murphy, Helena Christensen, Isabeli Fontana, Karen Alexander, Karen Elson and Lara Stone while they walk through the streets of New York. They walk among ordinary people and we feel like they want to be common people wrapped up in their thoughts. Their unveiled thoughts, which are not conveyed by their bodies nor by their actions, mostly fascinate the viewer who can be captured by this illusory normality and heaviness of their being wistful. They move and then stray from the camera and again stare at it, thus offering us a closeup that talks about them as women. In this fashion film there is no narrative plot, meaning that no characters' evolution is provided, but these bodies still allude to these women' personal story by staging their different personalities and ways of feeling - the firm lines of the New York majestic buildings are opposed to the softness of their gestures and are sometimes slowed down by an editing that expands the duration of their movements. Thanks to the musical box that accompanies the entire video, this editing choice projects the viewer in a hybrid dimension, between the real and the imaginary.

The narrative body is also that body that narrativizes and thematises, as we can see in fashion films with a narrative plot, for example in the Kenzo's fashion film for the SS 2018, Yo! My Saint. In this fashion film, the director Ana Lily Amirpour proposes a Japanese version of Blow Up (by the aforementioned Antonioni) - it's about the seduction story between the photographer and his model, which is mediated by the camera. On the photographic set, the dressed yet true girl's body is opposed to a mannequin's naked, cold and still body, which is unable to communicate and provoke emotions (even if hostile and dangerous), because emotions can create addiction.
The narrative body often develops an idea, which represents a key concept for the brand's visual identity. It's the case of Gucci, Pre-Fall 2018, and again directed by Glen Luchford.

\begin{abstract}
Michele along with lens man Glen Luchford and art director Christopher Simmonds, have reflected on university campus protest of 1968 Paris for inspiration. That moment was ripe with French Nouvelle Vague of the late Fifties and Sixties - a movement comprised of the inspiration of rebellious filmmakers François Truffaut and Jean-Luc Godard. During the month of May 1968, radical change was occurring in Paris as students, hungry for change, marched on the Sorbonne University. This time of immense change was fuelled by the fresh cultural lingual of Jean-Paul Sartre's existential philosophy of rock ' $n$ ' roll and a new era of participatory democracy. (Retrieved from www.theimpression.com)
\end{abstract}

These bodies speak about the history of a generation, about fights, protests and rebellions of the 1968 youth: they fought against traditions and clichés and told their desire to change the world by proving their being different from the past. These stories appear consistent to a brand that wants to address a young and cultured public, which wants to go against the grain. It's a brand that is proposing its revolution in fashion in terms of product, target, and language.

The narrative body seems to be the direct emanation of that aforementioned narrating body of the fashion photographs starting from Avedon. With fashion films, that body releases its communicative potential and completes the narration with movements and sounds thus becoming story. It could be very interesting to investigate the new kinds of fashion stories.

\section{A.2. Different is the case of the hyper- realistic body.}

We consider the term "hyper-realism" in connection to art: hyper-realism means an image so extremely faithful to reality up to the tiniest details, which embraces a technical perfection often comparable 
to the photographic quality, yet aggressive sometimes.

In a general backdrop of the routine aesthetisation, which is an attitude that has been lasting for few decades (let's think at Pop art and Op Art of the '60s), we move to a semiotic materialization of art culture officialises everything in terms of signs and signs circulation and transcribes everything into cultural, aesthetic and museographic terms. Baudrillard warns against this risk and, in the art of disappearance, he states:

In the images I see in America or Europe - be they video images, paintings, products of the plastic arts, or audio-visual or synthesized images - are literally images in which there is nothing to see. They leave no trace, cast no shadow, and have no consequences. (...) The only feeling one gets from such images is that behind each one there is something that has disappeared. And they are but this: the trace of what has disappeared. (...) Once freed from reality, we can produce the "realer than real" hyperrealism. It was in fact with hyperrealism and pop art that everything began, that everyday life was raised to the ironic power of photographic realism. (Baudrillard, 1988, p. $48-49$, translated by author)

And fashion seems to have followed a similar path in the New Millennium: a body realer than real is shown in some fashion films, a body dissected, scanned, almost radiographed by the camera, unreservedly and shamelessly.

A perfect example is the fashion film by Rankin for the perfume S\&X launched in November 2017. Besides the recent Hunger, Rankin is the British artist who cofounded AnOther Magazine with Jefferson Hack in 2001, and even before gave life to Dazed \& Confused.

In his $S \& X$ unisex perfume, designed by the award-winning fragrance designer Azzi Glasser, he tells three stories of touching bodies, no matter who they are, because there is always something to share when skin touches skin. In one of the three, the bodies of an old man and woman cling to one another - the camera lingers on these bodies' details and unveils their erogenous zones, as well as their sighs and the desires of these bodies that have changed so much over the years. It dwells with impunity and almost complacently on the folds of their old skin. No full bodies are shown, but rather a puzzle of images to recompose in our mind, thus defiantly giving more room to the beholder's imagination. These two bodies convey eroticism to the limit of pornography and without any pleasure.

A body shown in its hyper-realism, and therefore no beautiful nor ugly (as Baudrillard would say), is what we often find in Saint Laurent's fashion films. In the Winter 2017 film by Nathalie Canguilhem, the male models are shown in a sort of box or squared room with numerous pipes like those of the makeovers scaffolding. Everything is surrounded by the darkness with a metallic blue light and alienating music the models move in this environment and have an exaggerated skinny body, on the borderline of anorexia. Especially in one frame, the camera lingers on the bony abdomen of a boy by highlighting his bone structure and showing a small scar - the models never smile and their gaze sometimes challenges and invites us to enter in that borderline dimension. We could do plenty of examples (it's worth mentioning the fashion film "Brighton Sorts" made by Nick Knight and Britt Lloyd for a Vogue British Editorial published on April 2018), but what we would like to point out is how today the fashion images in magazines often use the same language. In fact, they dissect and explore the human body from top to bottom to generate types of images that were really rare in the last Millennium. We can think at some Solve Sondsbo's images (such as those published on November 2017 in a Vogue editorial entitled "Utopia") or those by Toiletpaper, a creative laboratory founded by Maurizio Cattelan and Pierpaolo Ferrari, or some photographs by Brigitte Niedermair (Wallpaper Magazine, March 2018 editorial).

Alongside these bodies narrated by the fashion films, whose human aspect and recognizable physicality are however shown, there is another way of narrativizing the body: the abstract body manner. 
B. Now we analyse the Abstract Body.

The innovative choice is not to show the body as expression of a concept, which was already done by fashion in the past as we have also mentioned, but what's innovative in the Abstract Body of the New Millennium is the absence of that aesthetical pleasure typical of the history of fashion images.

The Abstract Body is an unreal and dematerialised body whose representation is theatre-like dramatized so as to create an intense gap between the observed and the observer.

An artificial veneer invades the creature and creeps under the skin - in fashion images, the plastic body alternates with the real body, thus triggering a mashup of the skin and the inwardness of the subject.

This body interpretation embodies also some artists and contemporary singers - it's worth mentioning Lady Gaga for example who, even if often naked, has frequently displayed her body as a surface on which to draw her artistic vein. In the fashion film related to her perfume by Steven Klein, The Fame, she stages her avatar: a provocative, fame-hungry woman who turns into a monster surrounded by a dreamlike imagery that celebrates the aesthetic criteria of ugliness and grotesque. The bodies belonging to this category do not emerge as bodies to dress but are rather surface-bodies that translate the constant becoming.

We can also define two categories in this sector - the mutant body and the illusion body.

B.1. Within the first category we find the mutant body, namely a body embodying transmutation rather than disguise and standing elsewhere with a sort of theatrical complacency. The effect on the viewer is similar to Brecht's estrangement (18981956) - a "distancing effect" that warns the viewer who no longer identifies himself with what he is witnessing as it is evidently distant from his real world.

A mutant body, in fact, is a fake body, an artefact, a sort of man-made avatar. This body reminds us of Surrealism, the artistic movement born at the beginning of the past century. As it happens in Surrealism images, this body seems to be far from any aesthetic-related concern - its ambition is not to show itself as an expression of beauty or reality or an excellence of what is real, it is rather the protagonist of a beyond-reality, in a virtual or dreamlike dimension. This body represents a new subconscious where everything is overtly fake, as it is a product of the creator's imagination. This body is sometimes projected into the future at a high speed, changing constantly like some images of the '20s Futurism. The bodies defined here as mutant bodies belong to imaginary and distant worlds from reality, likewise they seem to set up the fashion dream we are currently experiencing, between the need of running away and the quest for a new balance.

In our view, the mutant body is declined in other two different interpretations: the doll body and the cyber body.

B.1.a The doll body is overtly and intentionally created to be staged for a hyperbolic world - it's the body of the androids who have acquired human traits to replace them. The filmmaker and photographer Tim Walker is certainly one of the best interpreters of this sort of body. In his fashion film Mechanical Dolls (2011), a group of models are displayed not just with the look but also the typical movements of the puppets, which seem to be guided by a species of puppeteer who is in turn puppet. They are will-less doll-bodies, incapable of emotions and consciousness. Their hard slap looks like a mask that does not betray their true identity.

In Like a Doll, another fashion film for Vogue Italia January 2012, Tim Walker shows us the model Lindsay Wixon making human yet repetitive movements in a sort of dollhouse and evidently pleased in this woman-doll hybrid dimension.

It's worth mentioning Steven Klein, another great interpreter of this type of bodies set in a urban and futuristic context. A perfect example is Kate Moss for Alexander McQueen SS2014, who is shown in a platinum blonde version holding a voodoo doll, which is her duplicate that will be thrown in a bin by herself. The atmosphere is definitely dark: the colours, en- 
vironment, feelings inspired by the video accompany a kind of unsolved foreboding, thus reminding us Alexander McQueen's world. It depicts a nightmare where emotions, fears, anxieties of this woman are the absolute protagonists rather than the actions she does, which are instead quite incomprehensible. In this context, it's noteworthy to mention Philipp Plein's fashion films, such as that made for the FW 2016-2017 by Steven Klein where mechanically animated toys mingle with human figures of different genders and ages and seem to join all together what looks like a game. The bodies displayed look mechanical and jerk, also due to an editing choice that wants to highlight this aspect, and some of them are covered in tattoos.

In this regard, the brand Philipp Plein states:

In a neon-lit future world, filled with turmoil and danger, the battle between good and evil rages on. Under attack from invisible forces, everyone must choose a side in this epic fight to the end. The struggle is real but there is hope. We need to search deep inside ourselves to find the belief, strength and determination to become superhuman. We can harness hidden powers within us all. Regardless of gender, nationality or age, we can be heroes... Starring Chris Brown, Carmen Dell'Orefice, Soo Joo Park and Crystal Renn as the ultimate super team, the Autumn/Winter 2016 campaign features a cast of diverse characters. (Retrieved from Philipp Plein http://www. youtube.com)

B.1.b. On the other hand, the cyber-body reveals the merger between man and machine, a body that decomposes and recomposes, it melts and then restores its image, it transmutes and then returns to itself. As in Matrix movie, this body is often pixeled though in these fashion movies it appears as expression of the brand's harmony or disharmony. An example is the fashion film \#asif by Nick Knight and Simon Foxton (2015) for Vman magazine Here we find a mix and match of moving images with a psychedelic mood where each image appears and disappears in less than a second under our eyes. The result is a frenetic and chaotic new dimension. But this game of shapes can eventually remind us something similar to everyday life where every moment gets rapidly burned, where the online/offline experiences cause the endless and confused mix and match we live in, thus making us unaware victims of a technological pleasure.

It's a body that physically experiences its virtual dimension, as in the fashion film Amazing and out of control (2014) by Love Magazine starring Cara Delevigne, where the protagonist lays on a bed of candies, sings and smiles while she interacts with the emoji appearing on the screen which however seem to coexist with her inside the screen.

Likewise, in fashion film for Prada Real Fantasies by Atlantis Film for SS 2016, or in another one for the FW 2016 collection by fashion photographer and filmaker Steven Miesel, the models move in a space between the real and the unreal. In both movies, the models' physical reality is in contrast with the strong artificiality of the backdrops where their bodies take shape. The frames taken from these fashion films have then become the still images of the two advertising campaigns published on fashion magazines.

B.2. The other main category of the mutant body is the illusion body - a body that cancels the human figure and emphasizes the energy and force it gives off in the space it moves in. This body is pure abstraction and is complacent about its shapes in quest of extreme aesthetics. We can define the abstract body as illusion body, as it is the expression of a dancing dream or misleading metamorphosis. It is often expression of an amplified and sectioned movement, which is made possible by the latest hi-tech images. This body is fully plunged into a virtual and dreamlike "second life" where everything is a game that everyone can play. These bodies dance and fluctuate, thus supporting the musical notes of the fashion film soundtrack, as it happens in the Missoni SS 2018 fashion film, or better in the latest Rag\&Bone fashion film. The latter features an industrial shed location where all bodies, who are no longer slaves of the daily life greyness, 
unwind in harmonious dances and create synergies with the super-colourful people surrounding them.

This is the film Why can't get along:

\begin{abstract}
"Can we all get along?" This question posed by Rodney King during the Los Angeles riots in 1992, which began following the acquittals of the four officers that beat him, remains a relevant question over 25 years later given the political turbulence and turmoil that we are experiencing today in the US. "Why Can't We Get Along," the latest rag \& bone film feature alters the quote slightly but asks the same question at a time where society appears to be less in sync. (...) The concept started from the way people spend too much time on their phones and do not really see one another, said Wainwright at the film premiere at The Metrograph. "It morphed from there. We wanted to do something that was cool and creative and fun and visually very impactful. That's all we really cared about." (Retrieved from www. impression.com)
\end{abstract}

It's worth mentioning the fashion film Mine all Mine by Tell No One for Nowness. A wondrous ballet where clothes and music are the authentic protagonist is showed - the music draws the soul of garments and people are just their performers. As in a theatrical performance, a merger of dress and individual is displayed in order to reveal a state of mind. The end is especially interesting as it gives us a possible interpretation - clothes can indeed live without men or women, but men and women are just lifeless without clothes.

Likewise, the numerous fashion films by showstudio.com for Gareth Pugh deserve a mention, such as the film for FW 2009 where women walk and move in a sort of futuristic dance and their bodies look extremely bidimensional.

The illusion bodies remind us the ever-present close relationship between dance and fashion as well as between dance and cinema. This is why the dancing body properly finds its place also in the online fashion film. In Dance Serpentine by Lumiere Brothers (1897), Loile Fuller's body enlivens a magic display of colours with a continuous spiral movement, thus making his body abstract. Likewise, it's impossible not to mention Adolf de Meyer, the first fashion photographer as well as the first to make an amazing photo shoot with the great dancer Vaclav Nijinsky engaged in the rehearsals for the Après-midi d'un Faune show. This show aroused a huge controversy among the public due to its intense eroticism, which was portrayed by de Meyer's pictures.

However, some changes in the fashion films were possible thanks to the new media: just as the mutant body seems like an avatar, so too the illusion body is a body that was able to emancipate from the typical static nature of photography thanks to the filmic language of the online videos, and thus becoming expression of that movement and life that both clothes and fashion need. The frames of these short movies are sometimes captured by the fashion mags as static images and the result is a sort of ping pong between the plasticity and dynamism typical of the Haute Couture.

In short, our observations can be summarised in a scheme that we call "Moving bodies in fashion films":

As we previously mentioned, we think that these are the main current trends and we believe that what herein examined could allow us to share some conclusions. What stands out the most is that fashion films' net-aesthetics gives life to different kinds of storytelling bodies which seem to emancipate both women and men from old archetypes or beauty stereotypes. According to us, the greatest novelty is that the new bodies do not want to be admired nor liked as they do not show off flawless body shapes and sizes nor look for acceptance or confirmations. The new body achieves two different goals that are covered in two different ways:

, the first one is the importance of being, as it is evident when fashion films show a body that want to state a personality or simply her/his emotions, thus becoming expression of a self-focused, unique and, at the same time, changeable individuality. The message leads us to think that there is not a right way of being as the right choice is just being 
Figure 1: Moving bodies in fashion films

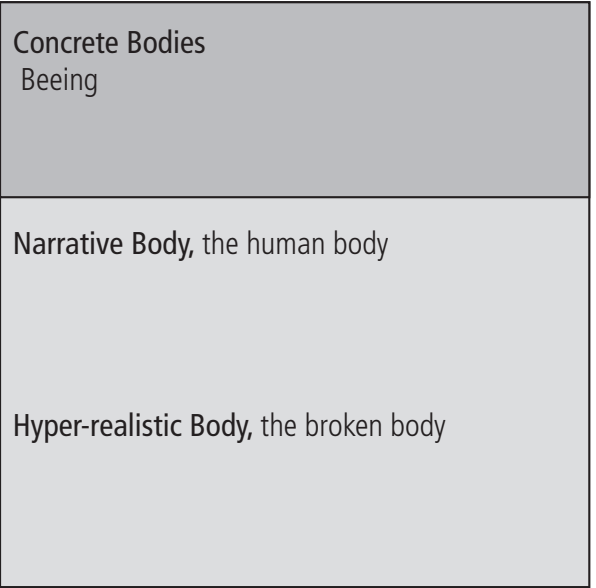

human, not perfect but authentic and living for feeling;

, the second one is the free adventure of not being, as it is evident when fashion films seem to be a sensory experience: in these films, the body enters in a surreal dimension where everything is possible and the viewer can loose himself/herself.

We fully agree with Uhlirova (2013) who states:

The fashion film does not always blatantly implicate the viewer as a consumer and has, generally, a greater degree of autonomy from the fashion it displays or connects, as it is less concerned with social and psychological processes of identification, persuasion and reassurance than is the case in more conventional marketing. And therein precisely lies its appeal for brands who are certainly not blind to the new marketing trends that eschew conventional advertising in favor of a more authentic experience. (Uhlirova, 2013, p. 121)

Fashion films therefore sense the current trends in society as well as the hypermodern consumer's apathy towards the traditional advertising, reason why they develop a new language for the online communication, which is often a decisive-

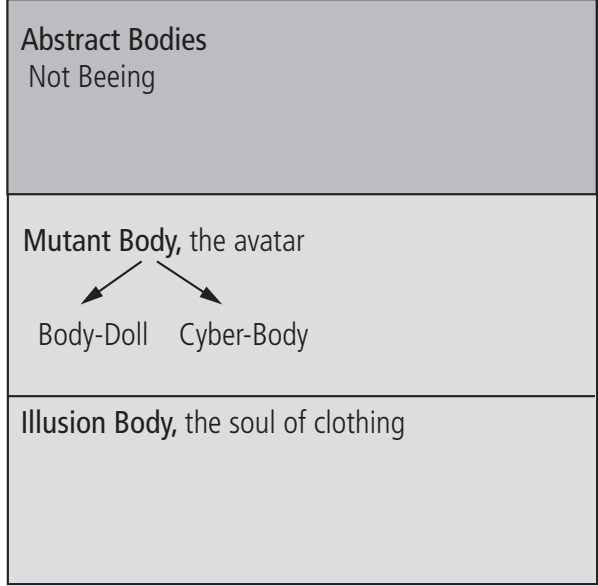

ly avant-garde brand communication as its goal is to produce a distant engagement from the traditional logics of persuasion.

Therefore the body, as the key code of this language and market, is no longer an aspirational model nor a classic idea of beauty, meant as a beauty of shapes. Indeed, it is rather a body that can tell stories about an extra-ordinary personality, as it is evident in the fashion images that often show us old women with a peculiar private history (such as Joni Mitchell, 71, for Saint Laurent; Joan Didion, 80, for Celine; Jessica Lange, 65, for Marc Jacobs Beauty; Charlotte Rampling, 69, for Nars; Catherine Deneuve, 71, for Louis Vuitton; and Anjelica Huston, 63, for Gap).

What stimulates our curiosity, and that should be deepened by further analysis, is the Beauty paradox in the Western countries, which is shown in these interpretations of the body in fashion: nowadays the Real Beauty is extending towards a Transmuting Beauty, which goes beyond the traditional boundary of the known and opts for the new post-modern or hyper-modern aesthetic world where nothing is set nor predetermined. This ever-connected and self-focused generation is producing a new era, which is characterized by new aesthetics (intended as performed Beauty) and where the border 
between real and unreal is weak: we call it Net-Aesthetics.

In our opinion, it is still important to verify if this language, which is so strongly affected by the Western social and aesthetic trends, could be well received by Countries where the consumption society has recently developed. Let's think at Russia, India or China. Looking at the fashion magazines editions in those Countries, we can notice how the models more or less reflect the classic idea of beauty translated in its "local forms" - in fact, in India the models are women with perfect and winding bodies, whereas the girls in China are still beautiful but much less curvy. Looking at those magazines, in fact, you have the impression of coming back to the '90s fashion images in Countries where the consumption society started many decades ago.

Analysing more in deep this topic would be really interesting, also because the language of images (as well as the verbal language) belongs to the culture and history of each population. Besides this, the risk of the Western brands is proposing fashion tales that use an incomprehensible or even neglected iconographic language by some populations.

\section{References}

Aaker, D., \& Joachimsthaler, E. (2009). Brand leadership. London: Simon and Schuster.

Angeletti, N., \& Oliva, A. (2012). In vogue. Milano: Rizzoli.

Barthes, R. (1967). Il sistema della Moda. Torino: Einaudi Editore.

Baudrillard, J. (2012). La sparizione dell'arte. Milano: Abscondita (original work published 1988).

Bippus, E., \& Mink, D. (2007). Fashion body cult. Stuttgart: Arnoldsche Verlagsanstalt.

Bourdieu, P. (1983). La distinzione. Critica sociale del gusto. Bologna: Il Mulino.

Brito, M. (2013). Your Brand. The next media company. Indianapolis USA: QUE Publishing.

Buffo, S. (2016), Fashion films and net-aesthetics. Journalism and Mass Communication,
6(7), New York: David Publishing, 409-419. doi:10.17265/2160-6579/2016.07.005

Buffo, S. (2017), Brand narration and fashion films. Journalism and Mass Communication, 7(6), New York: David Publishing, 292-304. doi:10.17265/21606579/2017.06.002

Buffo, S. (2012). Modalità espressive del fashion advertising. Milano: Franco Angeli Editore.

Codeluppi, V. (2012). Ipermondo. Roma-Bari: Laterza editore.

Duffin, C. (August 25, 2013). Miuccia Prada, head of luxury brand label, speaks of fascination with 'ugliness', Telegraph, Retrieved from http://www.telegraph.co.uk

Escalas, J. E. (2009). Self-referencing and persuasion: Narrative transportation versus analytical elaboration. Journal of Consumer Research, 33(4). 421-429. doi:10.1086/510216

Fabris, G. (2003). Il nuovo consumatore: verso il post-moderno. Milano: Franco Angeli Editore.

Fiorani, E. (2010). Abitare il corpo. Milano: Lupetti Editore.

Greimas, A.J. (1983). Del senso II. Milano: Bompiani Editore.

Jakobson, R. (2002), Saggi di linguistica generale, Milano: Feltrinelli (original work published 1963).

Kapferer, J.N, \& Bastien, V. (2010). The Luxury Strategy: Break the Rules of Marketing to Build Luxury Brand. London: Kogan Page.

Khan, N. (2012). Cutting the body. Fashion Theory, 16(2), 235-250, doi:10.2752/17517411 2X13274987924177

Kotler, P. (2016). Marketing 4.0. New Jersey: John Wiley.

Lehndorff, V., \& Trulzsch, H. (1986). Veruschka. Milano: Mondadori.

Marra, C. (2004). Nelle ombre di un sogno. Milano: Bruno Mondadori.

Newton, H. (1996). Proprietà privata. Milano: Tea Editore.

Pezzini, I. , \& Spaziante, L. (a cura di) (2014). Corpi mediali. Pisa: Edizioni ETS.

Sargeant, W. (November 8, 1958), A woman entering a taxi in the rain. The New Yorker, Profiles. Richard Avedon. Retrieved from http://www.newyorker.com

Shinkle, E. (2013). Fashion digital body: seeing and feeling in fashion interactives. In D. Bartlett, S. Cole., \& A. Rocamora 
(Eds.), Fashion Media, Past and Present (pp. 175 -183). London: Bloomsbury.

Smith, M. (2017). The native advertising advantage. London: McGraw-Hill Education Europe.

Uhlirova, M. (2013). The fashion film effect. In D, Bartlett, S. Cole, \& A. Rocamora (Eds.), Fashion Media, Past and Present (pp. 118 -129). London: Bloomsbury.

Uhlirova, M. (2013). 100 Years of the fashion films. Fashion Theory, 17(2), 137-158, doi:1 $0.2752 / 175174113 X 13541091797562$

Vogler, C. (2007). The writer's journey. San Francisco: Michael Wiese Productions.

Žižek, S. (2010). The matrix. Milano, Udine: Mimesi Edizioni. 
